\title{
Host-microbiota interactions within the fish intestinal ecosystem
}

\author{
T Pérez ${ }^{1}$, JL Balcázar $^{2}$, I Ruiz-Zarzuela ${ }^{1}, \mathrm{~N} \mathrm{Halaihel}^{1}, \mathrm{D} \mathrm{Vendrell}^{1}$, I de Blas ${ }^{1}$ and JL Múzquiz ${ }^{1}$
}

Teleost fish are in direct contact with the aquatic environment, and are therefore in continual contact with a complex and dynamic microbiota, some of which may have implications for health. Mucosal surfaces represent the main sites in which environmental antigens and intestinal microbiota interact with the host. Thus, the gut-associated lymphoid tissues (GALT) must develop mechanisms to discriminate between pathogenic and commensal microorganisms. Colonization of intestinal mucosal surfaces with a normal microbiota has a positive effect on immune regulatory functions of the gut, and disturbance in these immune regulatory functions by an imbalanced microbiota may contribute to the development of diseases. Significant attention has therefore been recently focused on the role of probiotics in the induction or restoration of a disturbed microbiota to its normal beneficial composition. Given this, this article explores the fascinating relationship between the fish immune system and the bacteria that are present in its intestinal microbiota, focusing on the bacterial effect on the development of certain immune responses.

\section{INTRODUCTION}

The structure and composition of the gut microbiota in fish is influenced by its surrounding environment, in which diverse microbial species compete with each other for space, nutrients, and available energy. ${ }^{1,2}$ Because conventional characterization of microorganisms has depended on cultivation-based techniques, our understanding of the gut microbiota is restricted to those that can be cultured. However, modern molecular methods, such as broad-range sequencing of $16 \mathrm{~S}$ ribosomal RNA from amplified nucleic acid, indicate evolutionary divergence that can be used to identify and classify microorganisms. The availability of sequence data has facilitated the development of molecular probes for fluorescence in situ hybridization and DNA microarrays that can identify and enumerate specific species. ${ }^{3}$ Recent studies are now finding that hostmicrobiota interactions are essential to many aspects of normal physiology, ranging from metabolic activity to immune homeostasis. ${ }^{4}$ With the availability of new tools to examine complex microbial communities and the growing appreciation for the importance of the indigenous microbiota, this review will focus on the role of the microbiota in fish health status and how the immune system adapts to the presence of microorganisms in the fish gastrointestinal tract.

\section{HOST-MICROBIOTA COMMUNICATION IN THE GUT}

Fish intestinal mucosal surfaces interface with a complex and dynamic community of microorganisms. Although the composition of intestinal microbiota depends on genetic, nutritional, and environmental factors, it is generally accepted that the fish gut harbors an estimated $10^{7}-10^{8}$ bacteria per gram. ${ }^{2,5}$ Members of the genera Aeromonas, Alcaligenes, Alteromonas, Carnobacterium, Flavobacterium, Micrococcus, Moraxella, Pseudomonas, and Vibrio constitute the predominant intestinal microbiota of a variety of marine fish species. In contrast to marine fish, the intestinal microbiota of freshwater fish species tend to be dominated by members of the genera Acinetobacter, Aeromonas, Flavobacterium, Lactococcus, and Pseudomonas, representatives of the family Enterobacteriaceae, and obligate anaerobic bacteria of the genera Bacteroides, Clostridium, and Fusobacterium. ${ }^{2,5}$ In rare circumstances these microorganisms cause disease, either directly, by damaging or traversing epithelial layers, or indirectly, by inducing tissue-damaging inflammatory responses. ${ }^{2}$ If microbial pathogens invade the host, innate and adaptive defense mechanisms are activated for preventing further spread of the infection. In healthy hosts, the intestinal immune system is hyporeactive, but it is capable to mount an extensive immune reaction against pathogenic bacteria. ${ }^{6}$ However, in addition to responding to these sporadic confrontations with microbial pathogens, the immune system must also properly calibrate responses to frequent confrontations with non-pathogenic commensal and microorganisms from the external environment. ${ }^{3}$ It is well documented that gut

\footnotetext{
${ }^{1}$ Laboratory of Fish Pathology, Faculty of Veterinary Sciences, Universidad de Zaragoza, Zaragoza, Spain. ${ }^{2}$ Catalan Institute for Water Research (ICRA), Scientific and Technological Park of the University of Girona, Girona, Spain. Correspondence: JL Balcázar (jlbalcazar@icra.cat) 
microbiota is essential for intestinal development, homeostasis, and protection against pathogenic challenges, to the point that some investigators have referred to it as an "extra organ" of the host. ${ }^{7}$ The gut represents the natural interface between intestinal microbiota and the host; in fact, the mucosal surfaces of the gastrointestinal tract are the main sites in which environmental microorganisms and antigens interact with the host, through intensive cross-talks. ${ }^{8}$ Thus, the first line of defense is provided by the mucus layer, which covers the epithelium and contains various protective and antimicrobial substances secreted by epithelial cells, including complement components, mucins, enzymes, piscidins, and defensins. ${ }^{9,10}$

With intestinal microbiota in continuous direct contact with the gut mucosa, the gut-associated lymphoid tissue (GALT) must develop mechanisms to distinguish between potentially pathogenic microorganisms and commensal microbiota, and to determine whether tolerance or an immune response should be induced. GALT contains important regulatory cells of the mucosal immune system such as lymphocytes, which are equipped to organize and mount rapid, selective, and potent immune responses against harmful foreign pathogens and phagocytes, which have a role in the sampling, presentation, and destruction of pathogens. ${ }^{11}$ Commensal bacteria exert an effect as an important antigenic stimulus for the maturation of GALT implicated in the induction of local immune responses. Immunoglobulin A is the most abundantly produced immunoglobulin isotype at the surface of mucous membranes in mammals, which is capable of entering Peyer's patches across $\mathrm{M}$ cells and targeting dendritic cells that may direct bacteria in the form of immune complexes into the GALT to permit continuous immune stimulation under non-inflammatory conditions. ${ }^{12}$ Intestinal bacteria are essential for the normal development of
GALT. In the absence of luminal bacteria, B cells and T cells do not home to the lamina propria of the intestine, and immunoglobulin A is not secreted. ${ }^{13}$

GALT in teleost fish lacks specialized structures-such as Peyer's patches in mammals-but the intestinal mucosa contains lymphocytes, plasma cells, granulocytes, and macrophages in the epithelial cells or disseminated throughout the lamina propria. ${ }^{14}$ In this sense, Lactobacillus delbrueckii ssp. delbrueckii, isolated from intestinal microbiota of adult sea bass (Dicentrarchus labrax), was administered to sea bass larvae and post-larvae to investigate the effects on development and differentiation of GALT, and it was observed that the number of T cells and acidophilic granulocytes in treated fish was significantly higher than in controls. ${ }^{15}$

Intestinal epithelial cells process the combined information from the luminal microbiota and the intestinal immune system. In consequence, the activation status and immune regulatory function is dependent on the kind of bacteria and immunederived stimuli they receive. Intestinal epithelial cells are capable of sensing components of the microbiota through the expression of pattern recognition receptors. ${ }^{6}$ One of the most representative members of pattern recognition receptors is the Toll-like receptor family; these receptors recognize bacterial lipopolysaccharides and other characteristic microbial molecules such as pathogen-associated molecular patterns. ${ }^{16}$ Toll-like receptors help direct the immune response by activating signaling events that increase expression of soluble mediators, which recruit and regulate the immune and inflammatory cells that initiate or enhance immune responses (Figure 1). ${ }^{17}$ These mediators can exert an effect locally to recruit other immune cells to the site of activation, or can exert an effect systemically to mediate a systemic immune response. Important soluble mediators

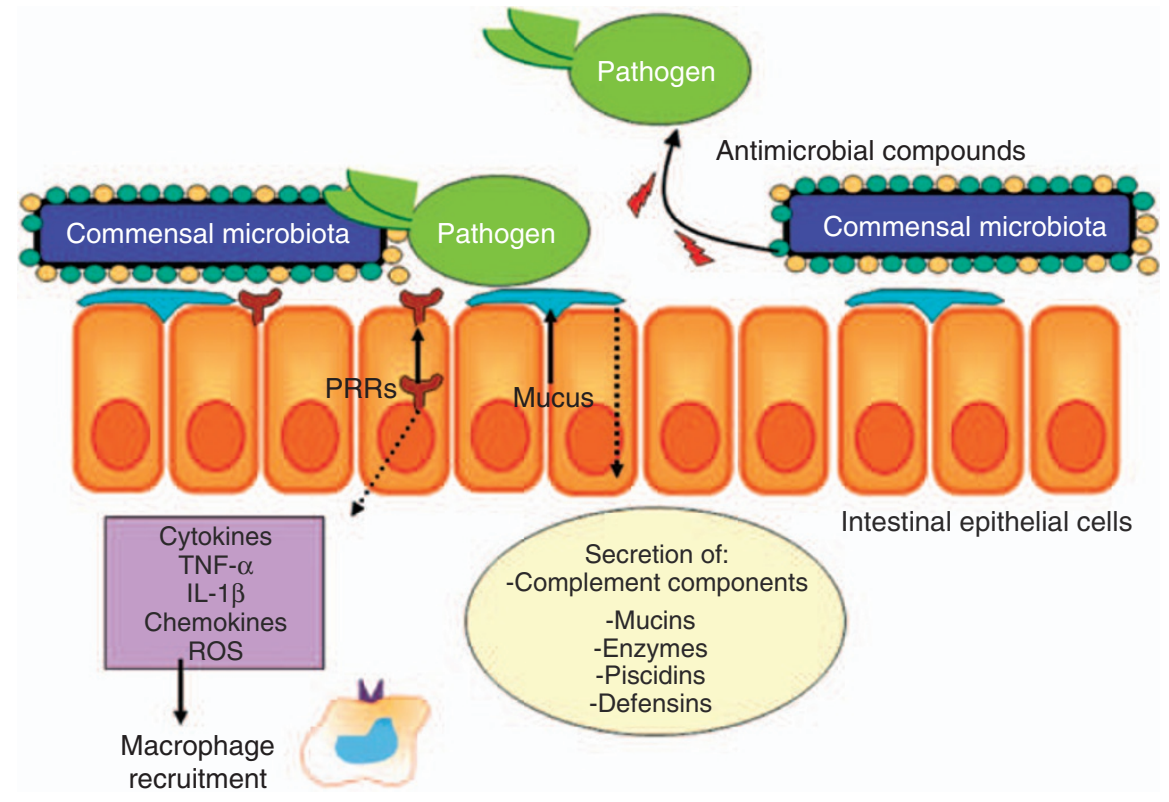

Figure 1 Mucosal immune system discriminates between pathogenic and commensal bacteria through pattern recognition receptors (PRRs), which mediate the detection of bacterial antigens and activate signaling cascades that regulate immune reactions (cytokines). Commensal bacteria (probiotics) can provide protection through the creation of a hostile environment for pathogenic bacteria by the production of inhibitory compounds, by competing for adhesion sites, or by modulating the immune response. 
include the inflammatory cytokines, tumor necrosis factor$\alpha$, interleukin- $1 \beta$ (IL-1 $\beta$ ), chemokines, and reactive oxygen species, including superoxide and nitric oxide, as well as the anti-inflammatory cytokine IL-10. ${ }^{18-20}$ Activation by pathogen-associated molecular patterns also stimulates the expression of a distinctive subset of microbial defense mediators that are specific for the particular Toll-like receptor activated. ${ }^{21}$ In fact, Picchietti et al. ${ }^{15}$ quantified transcripts of immune-related genes (CD4, CD8- $\alpha$, Cox-2, immunoglobulin A, IL-1 $\beta$, IL-10, $\mathrm{T}$ cell receptor- $\beta$, and transforming growth factor- $\beta$ ) of the sea bass as markers of inflammation and cell-mediated immunity. Real-time PCR detected lower IL- $1 \beta$ transcripts, a typical proinflammatory cytokine, in probiotic group than in controls. Similarly, Cox-2, IL-10, and transforming growth factor- $\beta$ transcripts were reduced in probiotic group, indicating a trend toward downregulation of inflammatory genes. These data differ from a study with rainbow trout (Oncorhynchus mykiss), in which upregulation of IL-1 $\beta_{1}$ and transforming growth factor- $\beta$ transcripts was observed in the spleen and head kidney after dietary administration of freeze-dried forms of Lactobacillus rhamnosus and Enterococcus faecium. ${ }^{22}$

In addition, to resolve the question of how the intestine calibrates its response against high lipopolysaccharide loads, Bates et al. ${ }^{23}$ have recently shown that the zebrafish intestinal alkaline phosphatase is required to detoxify lipopolysaccharide and to prevent intestinal inflammation in response to the resident microbiota.

\section{PROBIOTICS}

Colonization of intestinal mucosal surfaces with a normal microbiota has a positive effect on immune regulatory functions, and disturbance of these functions by an imbalanced microbiota may contribute to the development of diseases. In fact, Rawls et al. ${ }^{4}$ have shown that the establishment of the gut microbiota in zebrafish results in the induction of a complex pattern of gene expression. The genes expressed include those involved in stimulation of epithelial proliferation, promotion of nutrient metabolism, and innate immune responses. Significant attention has therefore been recently focused on the role of probiotics in the induction or restoration of a disturbed microbiota to its normal beneficial composition. Probiotics have been defined by the World Health Organization-Food and Agriculture Organization as "live microorganisms which when administered in adequate amounts, confer a health benefit on the host."

The use of probiotic bacteria has been applied in human and animal nutrition with successful results. ${ }^{25}$ In the past 10 years there has been a growing interest in fish farming to control diseases through alternative methods, such as probiotics. ${ }^{26,27}$

Recent evidence shows that some members of lactic acid bacteria, notably the genera Lactococcus and Carnobacterium, are important transient or permanent inhabitants in the gastrointestinal tract of fish. ${ }^{28-30}$ They are believed to exert several beneficial effects there, such as nutritional contribution and protection against pathogens, either by the production of antimicrobial compounds or through competition for mucosal binding sites. ${ }^{31}$ They are also vital to modulating interactions with the environment and the development and/or activation of beneficial immune responses associated with the mucous membranes that line the epithelial surfaces. ${ }^{28,32}$

A wide range of microalgae (Tetraselmis), yeasts (Debaryomyces, Phaffia, and Saccharomyces), and Gram-positive (Bacillus, Carnobacterium, Enterococcus, Lactobacillus, Lactococcus, Micrococcus, Streptococcus, and Weissella) and Gram-negative bacteria (Aeromonas, Alteromonas, Phaeobacter, Pseudomonas, and Vibrio) have been applied as probiotics to improve aquatic animal growth, survival, health, and disease prevention. ${ }^{26,27}$ Table 1 shows lactic acid bacteria and other microorganisms that are currently being used as probiotics, either singly or in combination. In this context, we have shown that feeding rainbow trout with members of its intestinal microbiota, such as Lactobacillus sakei, Lactococcus lactis, or Leuconostoc mesenteroides, for 2 weeks resulted in a higher survival rate after challenge with Aeromonas salmonicida. All three probiotic strains colonized the fish gastrointestinal tract and antagonized the populations of $A$. salmonicida, which initially infects the intestine and induces furunculosis in various wild and farmed fish species. In addition, there was a correlation between colonization with these probiotic strains and innate immune responses such as phagocytic activity and alternative complement pathway activity. ${ }^{33}$

Phagocytosis is responsible for early activation of the inflammatory response before antibody production, and is mediated by phagocytic cells, such as neutrophils, monocytes, and macrophages, in fish. The in vivo activation of phagocytic cells by immunomodulators may also lead to the secretion of a wide range of biologically active molecules, such as enzyme inhibitors, cationic peptides, and complement components, and to the production of reactive oxygen and nitrogen species that are involved in bactericidal activity. ${ }^{34,35}$ Moreover, activation of the complement system initiates a cascade of biochemical reactions accompanied by the generation of biologically active mediators that result in antigen elimination through cell membrane lysis and activation of nonspecific mediators of inflammation. ${ }^{36}$

We have also shown that the administration of $L$. mesenteroides and Lactobacillus plantarum confers protection against Lactococcus garvieae in rainbow trout. ${ }^{37}$ Competition for nutrients and adhesion receptors could be the basis for this protection, as microbiological and molecular analyses have revealed the presence of these probiotic strains in the fish intestine. In addition, it is well known that the gastrointestinal tract constitutes a preferred target for colonization by L. garvieae, and thus probiotic strains may create a hostile environment for the establishment of this pathogen. ${ }^{38}$

Probiotic microorganisms consist mostly of bacterial strains, although the use of other microorganisms such as yeasts has also been explored. Recently, Reyes-Becerril et al. ${ }^{39}$ showed that administration of Debaryomyces hansenii resulted in an enhancement of the innate immune response in juvenile gilthead seabream (Sparus aurata). The mRNA transcript of Hep, immunoglobulin $M$, T cell receptor- $\beta$, nonspecific cytotoxic cell receptor protein 1 , major histocompatibility complex class II $\alpha$, 
Table 1 Probiotics used in fish and the effect on their host

\begin{tabular}{|c|c|c|}
\hline Host species & Potential probiotic & Effect on host \\
\hline $\begin{array}{l}\text { Epinephelus } \\
\text { coioides }\end{array}$ & $\begin{array}{l}\text { Lactobacillus } \\
\text { plantarum 7-40 }\end{array}$ & $\begin{array}{l}\text { Immune stimulation } \\
\text { and improved } \\
\text { survival after challenge } \\
\text { with Streptococcus sp. } \\
\text { or iridovirus. }{ }^{48}\end{array}$ \\
\hline $\begin{array}{l}\text { Oncorhynchus } \\
\text { mykiss }\end{array}$ & $\begin{array}{l}\text { Vibrio fluvialis } \\
\text { A3-47S, Aeromonas } \\
\text { hydrophila A3-51, } \\
\text { Carnobacterium sp. } \\
\text { BA211, Micrococcus } \\
\text { luteus A1-6 }\end{array}$ & $\begin{array}{l}\text { Immune stimulation } \\
\text { and improved survival } \\
\text { after challenge } \\
\text { with Aeromonas } \\
\text { salmonicida. }{ }^{49}\end{array}$ \\
\hline $\begin{array}{l}\text { Oncorhynchus } \\
\text { mykiss }\end{array}$ & $\begin{array}{l}\text { Lactobacillus } \\
\text { rhamnosus } \\
\text { ATCC } 53103\end{array}$ & $\begin{array}{l}\text { Immune stimulation } \\
\text { and improved survival } \\
\text { after challenge } \\
\text { with Aeromonas } \\
\text { salmonicida. }^{50,51}\end{array}$ \\
\hline $\begin{array}{l}\text { Oncorhynchus } \\
\text { mykiss }\end{array}$ & $\begin{array}{l}\text { Aeromonas sobria } \\
\text { GC2 }\end{array}$ & $\begin{array}{l}\text { Immune stimulation } \\
\text { and improved survival } \\
\text { after challenge with } \\
\text { Lactococcus garvieae } \\
\text { and Streptococcus } \\
\text { iniae. } 52\end{array}$ \\
\hline $\begin{array}{l}\text { Oncorhynchus } \\
\text { mykiss }\end{array}$ & $\begin{array}{l}\text { Carnobacterium } \\
\text { maltaromaticum B26, } \\
\text { Carnobacterium } \\
\text { divergens B33 }\end{array}$ & $\begin{array}{l}\text { Expression of cytokine } \\
\text { genes and improved } \\
\text { survival after challenge } \\
\text { with Aeromonas } \\
\text { salmonicida and } \\
\text { Yersinia ruckeri. }{ }^{28,53}\end{array}$ \\
\hline $\begin{array}{l}\text { Oncorhynchus } \\
\text { mykiss, } \\
\text { Salmo trutta }\end{array}$ & $\begin{array}{l}\text { Lactobacillus } \\
\text { sakei CLFP 202, } \\
\text { Lactococcus } \\
\text { lactis CLFP 100, } \\
\text { Leuconostoc } \\
\text { mesenteroides } \\
\text { CLFP } 196\end{array}$ & $\begin{array}{l}\text { Immune stimulation } \\
\text { and improved survival } \\
\text { after challenge with } \\
\text { Aeromonas } \\
\text { salmonicida. }^{32,33,54}\end{array}$ \\
\hline $\begin{array}{l}\text { Oncorhynchus } \\
\text { mykiss }\end{array}$ & $\begin{array}{l}\text { Lactobacillus } \\
\text { rhamnosus ATCC } \\
53103, \text { Bacillus } \\
\text { subtilis, Enterococcus } \\
\text { faecium }\end{array}$ & $\begin{array}{l}\text { Immune stimulation } \\
\text { and expression of } \\
\text { cytokine genes. }^{22}\end{array}$ \\
\hline $\begin{array}{l}\text { Oncorhynchus } \\
\text { mykiss }\end{array}$ & Bacillus subtilis AB1 & $\begin{array}{l}\text { Immune stimulation } \\
\text { and improved sur- } \\
\text { vival after challenge } \\
\text { with Aeromonas sp. } \\
\text { ABE1. } 55\end{array}$ \\
\hline $\begin{array}{l}\text { Oncorhynchus } \\
\text { mykiss }\end{array}$ & $\begin{array}{l}\text { Lactobacillus } \\
\text { plantarum CLFP 238, } \\
\text { Leuconostoc } \\
\text { mesenteroides } \\
\text { CLFP } 196\end{array}$ & $\begin{array}{l}\text { Competitive exclusion } \\
\text { and improved survival } \\
\text { after challenge with } \\
\text { Lactobacillus garvieae. }^{37}\end{array}$ \\
\hline $\begin{array}{l}\text { Oncorhynchus } \\
\text { mykiss }\end{array}$ & $\begin{array}{l}\text { Aeromonas sobria } \\
\text { GC2, Brochothrix } \\
\text { thermosphacta } \\
\text { BA211 }\end{array}$ & $\begin{array}{l}\text { Immune stimulation } \\
\text { and improved survival } \\
\text { after challenge with } \\
\text { Aeromonas bestiarum } \\
\text { and Ichthyophthirius } \\
\text { multifiliis. } 56\end{array}$ \\
\hline Sparus aurata & $\begin{array}{l}\text { Lactobacillus } \\
\text { delbrueckii } \\
\text { CECT 287, Bacillus } \\
\text { subtilis CECT } 35\end{array}$ & Immune stimulation ${ }^{41}$ \\
\hline
\end{tabular}

colony stimulating factor 1 receptor, $\mathrm{C} 3$, tumor necrosis factor$\alpha$, and IL-1 $\beta$ genes were significantly higher in head kidney from fish fed the yeast-supplemented diet.

Multistrain and multispecies formulations, which are more than one strain of the same species or closely related species, have been proven to have synergistic beneficial effects on the host health, although the underlying mechanisms remain unclear. In higher vertebrates, there is conclusive evidence that adequately designed multistrain probiotic formulations possess health-promoting effects that are lacking in monospecies probiotic diets. ${ }^{40}$ Some of the proposed mechanisms include greater survival, growth, viability, or adhesion to mucosal surfaces of one species in the presence of another species, the production of different enzymes or other proteins, the creation of a probiotic niche, and additive/synergistic effects of strainspecific properties. ${ }^{40-43}$ Salinas et al. ${ }^{41}$ studied the effect of either Lactobacillus delbrüeckii ssp. lactis or Bacillus subtilis or a combination of both strains on the innate immune response of gilthead seabream. They showed that increased phagocytic activity of the leukocytes from fish fed the monospecies diets disappeared at third week, whereas fish that received the multispecies diet maintained their greater leukocyte phagocytic ability. Moreover, cytotoxic activity, which had not varied during the first 2 weeks of feeding in any experimental group, was higher in the multispecies group at third week. Capkin and Altinok ${ }^{44}$ also reported the effects of a multistrain probiotic formulation (Enterobacter cloacae and Bacillus mojavensis) on prevention of yersiniosis in rainbow trout. After feeding fish with multistrain formulation for 60 days, the fish survival rate increased to $99.2 \%$ after challenge with Yersinia ruckeri compared with controls that had $35 \%$ survival rate. The successful multistrain treatment may be the result of an optimal combination of strain-specific properties.

The effect of the indigenous microbiota is restricted to not only immune response but also to the structure, function, and metabolism of the digestive tract of fish. The gut microbiota and, by the same token, probiotics have a strong effect on priming immunophysiologic regulation in the intestine's mucosal barrier, which has opened up new angles in the science of nutrition. ${ }^{8}$

Physiological effects that have been suggested include serving as a source of nutrients, vitamins, and enzymes, and contributing to the microbial breakdown of indigestible components such as chitin, $p$-nitrophenyl- $\beta$ - $N$-acetylglucosamine, cellulose, and collagen. ${ }^{45}$ Studies in freshwater angelfish (Pterophyllum scalare), oscars (Astronotus ocellatus), and the marine southern flounder (Paralichthys lethostigma) suggest that the intestinal anaerobic bacteria can perform a role in the digestive process of the fish by providing a variety of enzymes such as carbohydrases, phosphatases, esterases, lipases, and peptidases that help in the absorption of nutrients. ${ }^{46}$ According to Aly et al. ${ }^{47}$ the administration of B. subtilis and Lactobacillus acidophilus increased the body-weight gain and this could be attributed to the improved digestive activity by enhancing the synthesis of vitamins, cofactors, and enzymatic activity, with a consequent improvement in the digestion, nutrient absorption, and weight gain. 


\section{CONCLUSIONS}

The manipulation of the host microbiota may represent a new possibility in the prevention or management of pathological and physiological disorders. Probiotics are usually members of the normal indigenous microbiota, which has an important role in the health of animals, and their addition can assist in returning a disturbed microbiota to its normal beneficial composition. Better understanding of how bacteria are able to differentially modulate host cell function will result from the identification of bacterial cell constituents and corresponding host cell receptors that modulate downstream responses. It will be crucial to consider the role of microbial communities and provide new avenues to treat and prevent infections.

\section{ACKNOWLEDGMENTS}

This manuscript benefited from the comments of $\mathrm{J}$ McPherson and DN Menge. T Pérez was supported by a fellowship from the Department of Science and Technology, Government of Aragón.

\section{DISCLOSURE}

The authors declared no conflict of interest.

() 2010 Society for Mucosal Immunology

\section{REFERENCES}

1. Hansen, G.H. \& Olafsen, J.A. Bacterial interactions in early life stages of marine cold water fish. Microb. Ecol. 38, 1-26 (1999).

2. Gómez, G.D. \& Balcázar, J.L. A review on the interactions between gut microbiota and innate immunity of fish. FEMS Immunol. Med. Microbiol. 52, 145-154 (2008).

3. Pamer, E.G. Immune responses to commensal and environmental microbes. Nat. Immunol. 8, 1173-1178 (2007).

4. Rawls, J.F., Samuel, B.S. \& Gordon, J.I. Gnotobiotic zebrafish reveal evolutionarily conserved responses to the gut microbiota. Proc. Natl. Acad. Sci. USA 101, 4596-4601 (2004).

5. Austin, B. The bacterial microflora of fish. Sci. World J. 6, 931-945 (2006).

6. Hörmannsperger, G. \& Haller, D. Molecular crosstalk of probiotic bacteria with the intestinal immune system: clinical relevance in the context of inflammatory bowel disease. Int. J. Med. Microbiol. 300, 63-73 (2010).

7. O'Hara, A.M. \& Shanahan, F. The gut flora as a forgotten organ. EMBO Rep. 7, 688-693 (2006).

8. Montalto, M., D’Onofrio, F., Gallo, A., Cazzato, A. \& Gasbarrini, G. Intestinal microbiota and its functions. Dig. Liver Dis. Suppl. 3, 30-34 (2009).

9. Silphaduang, U., Colorni, A. \& Noga, E.J. Evidence for widespread distribution of piscidin antimicrobial peptides in teleost fish. Dis. Aquat. Org. 72, 241-252 (2006).

10. Zou, J., Mercier, C., Koussounadis, A. \& Secombes, C. Discovery of multiple beta-defensin like homologues in teleost fish. Mol. Immunol. 44, 638-647 (2007).

11. Acheson, D.W.K. \& Luccioli, S. Mucosal immune responses. Best Pract. Res. Clin. Gastroenterol. 18, 387-404 (2004).

12. Corthésy, B., Gaskins, H.R. \& Mercenier, A. Cross-talk between probiotic bacteria and the host immune system. J. Nutr. 137, 781S-790S (2007).

13. McClelland, D.B.L. Peyer's-patch-associated synthesis of immunoglobulin in germ-free, specific-pathogen-free, and conventional mice. Scand. J. Immunol. 5, 909-915 (1976).

14. Press, C.M. \& Evensen, O. The morphology of the immune system in teleost fishes. Fish Shellfish Immunol. 9, 309-318 (1999).

15. Picchietti, S. et al. Early treatment with Lactobacillus delbrueckii strain induces an increase in intestinal T-cells and granulocytes and modulates immune-related genes of larval Dicentrarchus labrax (L.). Fish Shellfish Immunol. 26, 368-376 (2009).

16. Tlaskalova-Hogenova, H. et al. Interaction of mucosal microbiota with the innate immune system. Scand. J. Immunol. 62, 106-113 (2005).

17. Fasano, A. \& Shea-Donohue, T. Mechanisms of disease: the role of intestinal barrier function in the pathogenesis of gastrointestinal autoimmune diseases. Nat. Clin. Pract. Gastroenterol. Hepatol. 2, 416-422 (2005).

18. Secombes, C.J. et al. Cytokines and innate immunity of fish. Dev. Comp. Immunol. 25, 713-723 (2001).

19. Mulder, I.E., Wadsworth, S. \& Secombes, C.J. Cytokine expression in the intestine of rainbow trout (Oncorhynchus mykiss) during infection with Aeromonas salmonicida. Fish Shellfish Immunol. 23, 747-759 (2007).

20. Zou, J., Clark, M.S. \& Secombes, C.J. Characterisation, expression and promoter analysis of an interleukin 10 homologue in the puffer fish, Fugu rubripes. Immunogenetics 55, 325-335 (2003).

21. Carpenter, S. \& O'Neill, L.A.J. How important are Toll-like receptors for antimicrobial responses? Cell. Microbiol. 9, 1891-1901 (2007).

22. Panigrahi, A. et al. Immune modulation and expression of cytokine genes in rainbow trout Oncorhynchus mykiss upon probiotic feeding. Dev. Comp. Immunol. 31, 372-382 (2007).

23. Bates, J.M., Akerlund, J., Mittge, E. \& Guillemin, K. Intestinal alkaline phosphatase detoxifies lipopolysaccharide and prevents inflammation in zebrafish in response to the gut microbiota. Cell. Host. Microbe. 2, 371-382 (2007).

24. FAOMHO. Report of a Joint FAO/WHO Expert Consultation on Evaluation of Health and Nutritional Properties of Probiotics in Food including powder milk with live lactic acid bacteria (Córdoba, Argentina, 2001).

25. Balcázar, J.L. Probiotics in health maintenance: do they really work? Br. J. Infect. Contro/ 8, 26-29 (2007).

26. Irianto, A. \& Austin, B. Probiotics in aquaculture. J. Fish Dis. 25, 633-642 (2002).

27. Balcázar, J.L., de Blas, I., Ruiz-Zarzuela, I., Cunningham, D., Vendrell, D. \& Múzquiz, J.L. The role of probiotics in aquaculture. Vet. Microbiol. 114, 173-186 (2006).

28. Kim, D.H. \& Austin, B. Innate immune responses in rainbow trout (Oncorhynchus mykiss, Walbaum) induced by probiotics. Fish Shellfish Immunol. 21, 513-524 (2006).

29. Balcázar, J.L., de Blas, I., Ruiz-Zarzuela, I., Vendrell, D., Gironés, O. \& Muzquiz, J.L. Sequencing of variable regions of the $16 \mathrm{~S}$ rRNA gene for identification of lactic acid bacteria isolated from the intestinal microbiota of healthy salmonids. Comp. Immunol. Microbiol. Infect. Dis. 30, 111-118 (2007).

30. Gatesoupe, F.J. Updating the importance of lactic acid bacteria in fish farming: natural occurrence and probiotic treatments. J. Mol. Microbiol. Biotechnol. 14, 107-114 (2008).

31. Balcázar, J.L., Vendrell, D., de Blas, I., Ruiz-Zarzuela, I., Gironés, O. \& Múzquiz, J.L. In vitro competitive adhesion and production of antagonistic compounds by lactic acid bacteria against fish pathogens. Vet. Microbiol. 122, 373-380 (2007).

32. Balcázar, J.L. et al. Changes in intestinal microbiota and humoral immune response following probiotic administration in brown trout (Salmo trutta). Br. J. Nutr. 97, 522-527 (2007).

33. Balcázar, J.L., de Blas, I., Ruiz-Zarzuela, I., Vendrell, D., Gironés, O. \& Muzquiz, J.L. Enhancement of the immune response and protection induced by probiotic lactic acid bacteria against furunculosis in rainbow trout (Oncorhynchus mykiss). FEMS Immunol. Med. Microbiol. 51, 185-193 (2007).

34. Adams, D.O. \& Hamilton, T.A. The cell biology of macrophage activation. Ann. Rev. Immunol. 2, 283-318 (1984).

35. Kwak, J.K., Park, S.W., Koo, J.G., Cho, M.G., Buchholz, R. \& Goetz, P. Enhancement of the non-specific defense activities in carp (Cyprinus carpio) and flounder (Paralichthys olivaces) by oral administration of Schizophyllan. Acta. Biotechnol. 23, 359-371 (2003).

36. Holland, M.C.H. \& Lambris, J.D. The complement system in teleosts. Fish Shellfish Immunol. 12, 399-420 (2002).

37. Vendrell, D., Balcázar, J.L., de Blas, I., Ruiz-Zarzuela, I., Gironés, O. \& Múzquiz, J.L. Protection of rainbow trout (Oncorhynchus mykiss) from lactococcosis by probiotic bacteria. Comp. Immunol. Microbiol. Infect. Dis 31, 337-345 (2008).

38. Vendrell, D., Balcázar, J.L., Ruiz-Zarzuela, I., de Blas, I., Gironés, O. \& Múzquiz, J.L. Lactococcus garvieae in fish: a review. Comp. Immunol. Microbiol. Infect. Dis 29, 177-198 (2006).

39. Reyes-Becerril, M. et al. Oral delivery of live yeast Debaryomyces hansenii modulates the main innate immune parameters and the expression of immune-relevant genes in the gilthead seabream (Sparus aurata L.). Fish Shellfish Immunol. 25, 731-739 (2008). 
40. Timmerman, H.M., Koning, C.J.M., Mulder, L., Rombout, F.M. \& Beynen, A.C. Monospecies, multistrain and multispecies probiotics: a comparison of functionality and efficacy. Int. J. Food. Microbiol. 96, 219-33 (2004).

41. Salinas, I. et al. Monospecies and multispecies probiotic formulations produce different systemic and local immunostimulatory effects in the gilthead seabream (Sparus aurata L.). Fish Shellfish Immunol. 25, 114-123 (2008).

42. Hosoi, T., Ametani, A., Kiuchi, K. \& Kaminogawa, S. Improved growth and viability of lactobacilii in the presence of Bacillus subtilis, catalase, or subtilisin. Can J. Microbiol. 46, 892-897 (2000).

43. Ouwehand, A.C., Isolauri, E., Kirjavainen, P.V., Tölkkö, S. \& Salminen, S.J. The mucus binding of Bifidobacterium lactis $\mathrm{Bb} 12$ is enhanced in the presence of Lactobacillus GG and Lact. delbrüeckii subsp. bulgaricus. Lett. Appl. Microbiol. 30, 10-13 (2000).

44. Capkin, E. \& Altinok, I. Effects of dietary probiotic supplementations on prevention/treatment of yersiniosis disease. J. Appl. Microbiol. 106, 1147-1153 (2009).

45. Ringø, E., Strøm, E. \& Tabachek, J.A. Intestinal microflora of salmonids: a review. Aquacult. Res. 26, 773-789 (1995).

46. Ramirez, R.F. \& Dixon, B.A. Enzyme production by obligate intestinal anaerobic bacteria isolated from oscars (Astronotus ocellatus), angelfish (Pterophyllum scalare) and southern flounder (Paralichthys lethostigma). Aquaculture 227, 417-426 (2003).

47. Aly, S.M., Ahmed, Y.A.G., Ghareeb, A.A.A. \& Mohamed, M.F. Studies on Bacillus subtilis and Lactobacillus acidophilus, as potential probiotics, on the immune response and resistance of Tilapia nilotica (Oerochromis niloticus) to challenge infections. Fish Shellfish Immunol. 25, 128-136 (2008).

48. Son, V.M., Chang, C.C., Wu, M.C., Guu, Y.K., Chiu, C.H. \& Cheng, W. Dietary administration of the probiotic, Lactobacillus plantarum, enhanced the growth, innate immune responses, and disease resistance of the grouper Epinephelus coioides. Fish Shellfish Immunol. 26, 691-698 (2009).

49. Irianto, A. \& Austin, B. Use of probiotics to control furunculosis in rainbow trout, Oncorhynchus mykiss (Walbaum). J. Fish. Dis. 25, 333-342 (2002).

50. Nikoskelainen, S., Ouwehand, A.C., Bylund, G., Salminen, S. \& Lilius, E.M. Immune enhancement in rainbow trout (Oncorhynchus mykiss) by potential probiotic bacteria (Lactobacillus rhamnosus). Fish Shellfish Immunol. 15, 443-452 (2003).

51. Nikoskelainen, S., Ouwehand, A., Salminen, S. \& Bylund, G. Protection of rainbow trout (Oncorhynchus mykiss) from furunculosis by Lactobacillus rhamnosus. Aquaculture 198, 229-236 (2001).

52. Brunt, J. \& Austin, B. Use of a probiotic to control lactococcosis and streptococcosis in rainbow trout, Oncorhynchus mykiss (Walbaum). J. Fish. Dis. 28, 693-701 (2005).

53. Kim, D.H. \& Austin, B. Cytokine expression in leucocytes and gut cells of rainbow trout, Oncorhynchus mykiss Walbaum, induced by probiotics. Vet. Immunol. Immunopathol. 114, 297-304 (2006).

54. Balcázar, J.L., Vendrell, D., de Blas, I., Ruiz-Zarzuela, I. \& Muzquiz, J.L. Effect of Lactococcus lactis CLFP 100 and Leuconostoc mesenteroides CLFP 196 on Aeromonas salmonicida infection in brown trout (Salmo trutta). J. Mol. Microbiol. Biotechnol. 17, 153-157 (2009).

55. Newaj-Fyzul, A., Adesiyun, A.A., Mutani, A., Ramsubhag, A., Brunt, J. \& Austin, B. Bacillus subtilis AB1 controls Aeromonas infection in rainbow trout (Oncorhynchus mykiss, Walbaum). J. Appl. Microbiol. 103, 1699-1706 (2007).

56. Pieters, N., Brunt, J., Austin, B. \& Lyndon, A.R. Efficacy of in-feed probiotics against Aeromonas bestiarum and /chthyophthirius multifiliis skin infections in rainbow trout (Oncorhynchus mykiss, Walbaum). J. Appl. Microbiol. 105, 723-732 (2008). 